\title{
A 2 month old infant with Chediak-Higashi syndrome presenting in the accelerated phase
}

\author{
*Vinoth Vadivel ${ }^{1}$, A M Vijayalakshmi ${ }^{1}$ \\ DOI: http://dx.doi.org/10.4038/sljch.v47i1.8435 \\ Sri Lanka Journal of Child Health, 2018; 47(1): 74-76
}

(Key words: Chediak-Higashi syndrome, accelerated phase)

\section{Introduction}

Chediak-Higashi syndrome (CHS) is an autosomal recessive disorder due to LYST/CHS1 gene mutation ${ }^{1}$. It is characterized by frequent bacterial infections, partial oculo-cutaneous albinism and abnormal large leucocyte granules ${ }^{1}$. It is also associated with clinical features involving the haematologic and neurologic systems ${ }^{2}$. In $85 \%$ cases, CHS enters an accelerated phase consisting of lympho-histiocytic infiltration of the liver, spleen, lymph nodes and bone marrow ${ }^{3}$. Once the accelerated phase has occurred, the disease is invariably fatal. There are only around 500 cases of CHS reported up to $2011^{4}$. According to the literature, onset of disease is from 2 months to 10 years ${ }^{5}$. However, the accelerated phase has only been reported in babies 9 months of age or more ${ }^{6}$. We report a 2 month old boy with CHS in the accelerated phase.

\section{Case report}

A 2 month old baby boy was brought to hospital with a history of fever for 5 days. He was the first child from a consanguineous marriage and was developmentally normal. There was no family history of CHS. He was febrile, weighed $4 \mathrm{~kg}$, and had blonde hair and hypopigmentation of the skin all over the body. He had pallor with cervical lymphadenopathy. Cardiovascular and respiratory system examinations were normal. He had a distended abdomen with hepatomegaly $(4 \mathrm{~cm})$ and splenomegaly $(7 \mathrm{~cm})$. He had no focal neurological deficit.

Laboratory investigations showed leucopenia $(3,100 / \mathrm{cu} \mathrm{mm})$, thrombocytopenia $(24,000 / \mathrm{cu} \mathrm{mm})$ and anaemia (haemoglobin $7.4 \mathrm{~g} / \mathrm{dl}$ ). Peripheral

\section{${ }^{1}$ PSG Institute of Medical Sciences and Research, India \\ *Correspondence: vadivelvinoth4@gmail.com}

(Received on 12 October 2016: Accepted after revision on 18 November 2016)

The authors declare that there are no conflicts of interest

Personal funding was used for the project.

Open Access Article published under the Creative

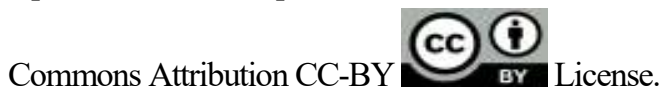

blood smear showed pancytopenia with lymphocytic inclusions. Child also had a high erythrocyte sedimentation rate $(72 \mathrm{~mm}$ in first hour), high serum ferritin levels $(>2000 \mathrm{ng} / \mathrm{ml})$, normal fibrinogen levels $(231 \mathrm{mg} / \mathrm{dl})$, and hypertriglyceridaemia $(325 \mathrm{mg} / \mathrm{dl})$. Bone marrow aspirate revealed large coarse azurophilic granules in the myeloid series and features of erythrophagocytosis in myeloid precursor cells (Figures 1 and 2).

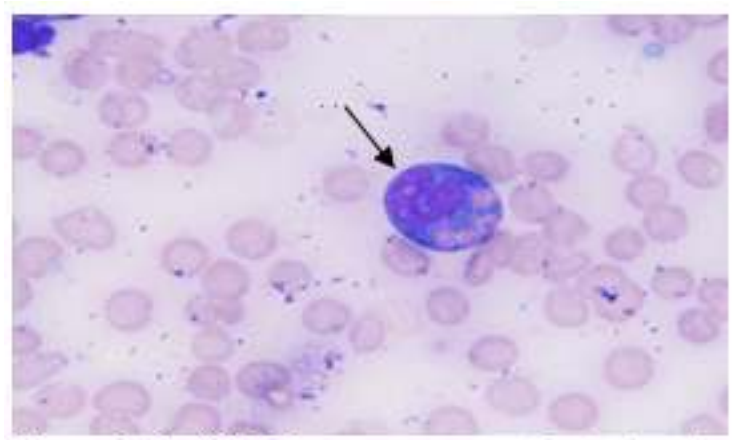

Figure 1 ( $x$ 400): Bone marrow aspirate showing azurophilic granules (shown by arrow)

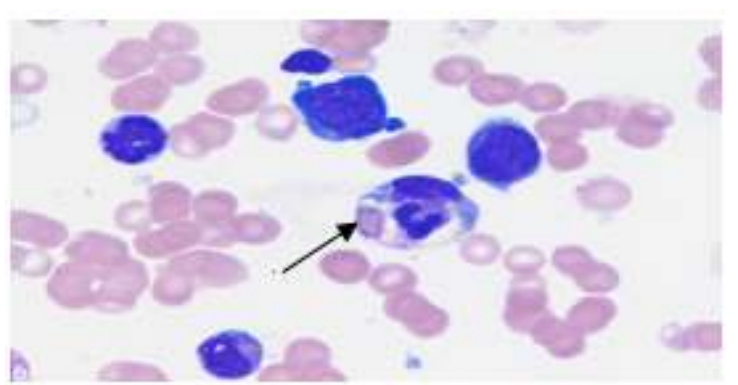

Figure 2 (x 400): Bone marrow aspirate showing erythrophagocytosis (shown by arrow)

The patient fulfilled the diagnostic criteria for haemophagocytic lymphohistiocytosis (HLH) viz. fever, splenomegaly pancytopenia, high serum ferritin levels, hypertriglyceridaemia and haemophagocytosis in the bone marrow. Thus, the diagnosis of accelerated phase of CHS was made on the basis of clinical presentation (hypopigmentation, blond hair) and haematological findings (giant azurophilic granules in leucocytes). Blood and urine cultures were sterile. Chest X-ray was normal. Abdominal ultrasound revealed hepatosplenomegaly. Optical microscopy of the hair showed groups of pigment scattered along the 
length of the hair shafts, contrasting with the normal pattern of fine, diffuse pigmentation (Figures 3 and 4). The child was treated with ceftriaxone and vancomycin. He also received transfusions, including platelets and packed red blood cells for anaemia. Child expired on $5^{\text {th }}$ day of hospitalisation.

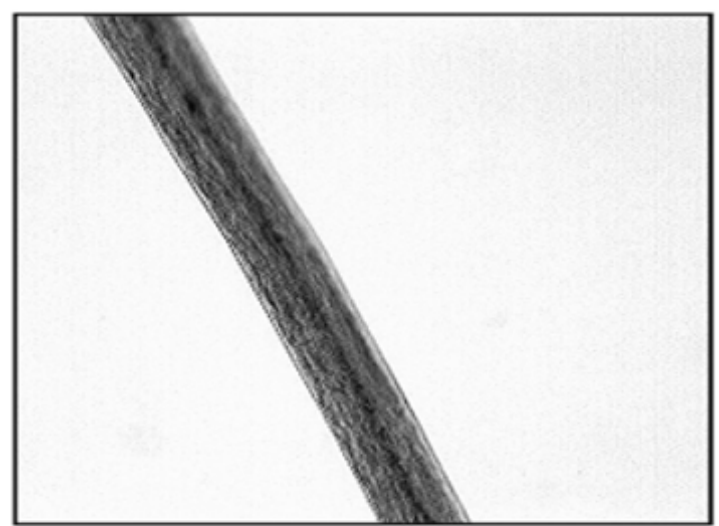

Figure 3: Microscopic examination of a normal hair shaft

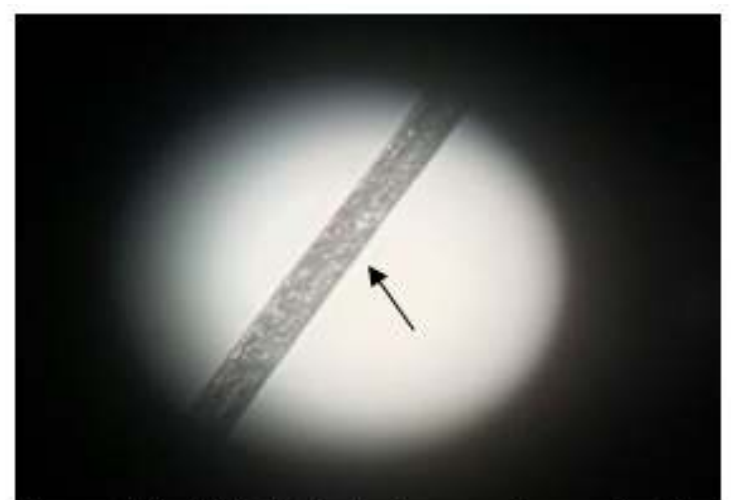

Figure 4 (x 400): Optical microscopic examination of the hair shaft showing Larger melanin granules (shown by arrow)

\section{Discussion}

CHS is a rare immunodeficiency disorder due to defective granulocyte function. Defective phagocyte, lymphocyte, and natural killer (NK) cell functions contribute to the enhanced susceptibility to infection ${ }^{7}$. The final stage of CHS is characterised by lymphohistiocytic cell infiltration in various organs ${ }^{4}$. Staphylococcus aureus, betahaemolytic streptococci and pneumococci are the common pathogens causing recurrent infections such as pneumonia, otitis media, dermal and mucosal infections ${ }^{8}$. Mental retardation and neural deafness have also been reported ${ }^{9}$. Diagnosis of CHS can be confirmed by the presence of LYST/CHS1 gene mutation ${ }^{1}$. The most important and hazardous complication of CHS is the acceleration phase, manifesting as fever, jaundice, hepato-splenomegaly and lymphadenopathy. The most effective treatment for CHS is allogenic haematopoietic stem cell transplantation (HSCT), but this therapy does not prevent the progressive neurological dysfunction frequently observed during long-term follow up ${ }^{10}$.

\section{References}

1. Ghaffari J, Rezaee SA, Gharagozlou M. Chediak-Higashi syndrome. Journal of Pediatrics Review 2013; 1(2):80-7.

2. Islam AS, Hawsawi ZM, Islam MS, Ibrahim OAH. Chediak-Higashi syndrome: an accelerated phase with hereditary elliptocytosis: case report and review of the literature. Annals of Saudi Medicine 2001; 21(3-4): 221-4. https://doi.org/10.5144/02564947.2001.22 1

PMid: 17264559

3. Boxer LA, Smolen JE. Neutrophil granule constituents and their release in health and disease. Hematology/ Oncology Clinics of North America 1988; 2(1):101-34.

PMid: 2831184

4. Reddy RR, Babu BM, Venkateshwaramma B, Hymavathi $\mathrm{CH}$. Silvery hair syndrome in two cousins: Chediak-Higashi syndrome vs Griscelli syndrome, with rare associations. International Journal of Trichology 2011; 3(2):107-11.

https://doi.org/10.4103/0974-7753.90825

PMid: 22223973 PMCid: PMC3250006

5. Haddad E, Le Deist F, Blanche S, Benkerrou M, Rohrlich P, Vilmer E, et al. Treatment of Chédiak-Higashi syndrome by allogenic bone marrow transplantation: report of 10 cases. Blood 1995; 85(1): 3328-33

PMid: 7756666

6. Bouatay A, Hizem S, Tej A, Moatamri W, Boughamoura L, Kortas M. ChediakHigashi syndrome presented as accelerated phase: case report and review of the literature. Indian Journal of Hematology and Blood Transfusion2014; 30(1):S223-6.

https://doi.org/10.1007/s12288-014-0336-

PMid: 25332584 PMCid: PMC4192156

7. Barak Y, Karov Y, Nir E, Wagner Y, Kristal H, Levin S:Chediak-Higashi syndrome: In vivo studies of granulocytemonocyteprogenitors. American Journal 
of Pediatric Hematology/Oncology1986;

8(2): 128-33.

PMid: 3740366

8. Bellinati-Pires R, Araujo MIAS, Grumach AS. Deficiências do sistemafagocitário. In: Carneiro-Sampaio MMS, Grumach AS, editors Alergia e Imunologiaem pediatria. 1st ed. São Paulo: Sarvier; 1992:165-6.

9. Kondo N, Shimozawa N, Asano J, Imamura A, Orii T. Chédiak-Higashi syndrome with cerebellar cortical atrophy detected by MRI. Clinical Genetics 1994; 46(6): 439-40.

https://doi.org/10.1111/j.13990004.1994.t b04414.x

PMid: 7889663
10. Kaplan J, De Domenico I, Ward DM. Chediak-Higashi syndrome. Current Opinion in Hematology 2008; 15(1):22-9. https://doi.org/10.1097/MOH.0b013e3282 f2bcce

PMid: 18043242 